\title{
HUBUNGAN ANTARA PERTUMBUHAN DENGAN KEBERADAAN GEN TAHAN PENYAKIT MAJOR HISTOCOMPATIBIUTY COMPLEX (MHC) PADA IKAN MAS (Cyprinus carpio)
}

\author{
Erma Primanita Hayuningtyas, Didik Ariyanto, dan Khairul Syahputra \\ Balai Penelitian Pemuliaan Ikan \\ Jl. Raya 2 Sukamandi, Subang 41256 \\ E-mail: erma_primanita@yahoo.com
}

(Naskah diterima: 9 April 2013; Disetujui publikasi: 12 September 2013)

\begin{abstract}
ABSTRAK
Wabah penyakit koi herpes virus (KHV) di Indonesia yang terjadi sejak tahun 2002 merupakan salah satu faktor yang memicu kemerosotan produksi ikan mas budidaya. Pembentukan strain unggul ikan mas tahan KHV dapat menjadi solusi bagi permasalahan tersebut. Pemilihan genotip ikan mas tahan KHV dengan marka molekuler gen major histocompatibility complex class II (MHC- II), khususnya pada alel Cyca DAB $1 * 05$ akan membantu dalam kegiatan seleksi. Penelitian ini bertujuan untuk mengetahui keberadaan gen MHC- II pada populasi dasar G0 ikan mas strain Rajadanu dan hubungannya dengan pertumbuhan (bobot). Metode deteksi keberadaan gen MHC- II pada dua kelompok ikan dengan ukuran berbeda dilakukan dengan teknik PCR. Hubungan antara pertumbuhan ikan mas dengan persentase kemunculan gen MHC-II dianalisis dengan menggunakan program SPSS (Statistical Package for the Social Sciences), sehingga diperoleh korelasi di antara keduanya. Hasil penelitian menunjukkan bahwa hubungan antara pertumbuhan dengan persentase keberadaan gen MHC- II berkorelasi negatif dengan nilai $R=-0,742$. Hal ini mengindikasikan bahwa semakin cepat pertumbuhan populasi ikan mas maka semakin sedikit persentase individu yang mempunyai gen MHC- II pada setiap populasi ikan mas. Sehingga populasi ikan mas yang pertumbuhannya lambat memiliki tingkat persentase positif MHC- II lebih tinggi $(85,71 \% 100 \%$ dibandingkan populasi ikan mas yang pertumbuhannya cepat $(42,86 \%$ $85,71 \%$.
\end{abstract}

KATA KUNCl: ikan mas, pertumbuhan, daya tahan, gen MHC- II, Koi Herpes Virus (KHV)

ABSTRACT: A correlation between growth character and presence of Major Histocompatibility Complex (MHC) gene as disease resistance marker in common carp (Cyprinus carpio). By: Erma Primanita Hayuningtyas, Didik Ariyanto, and Khairul Syahputra

The outbreak of koi herpes virus (KHV) disease that has been occurring in Indonesia since 2002 was triggering the decline of common carp production. Creating of superior strain of common carp KHV resistant can become one of the solution for this issue. Genotypes selection of KHV-resistant common carp associated molecular markers with specific Cyca DAB $1 * 05$ allele of major histocompatibility complex class II (MHCII) gene will assist in selection programe. The aim of this study was to determine the presence of MHC II gene in base population G0 of Rajadanu common carp strain and its correlation with growth (weight) character. PCR technique was used to detect the MHC-II gene presence in two different weight populations of common carp. Correlation between growth and presence of MHC-II gene was analyzed using SPSS (Statistical 
Package for the Social Sciences) software. The result showed that there was negative correlation between growth and MHC-II gene percentage with $\mathrm{R}$ value was -0.742 . This correlation indicated that there were low percentage individu having MHC-II gene within faster growth population of common carp. So that common carp population low growth (85.71\%-100\%) having percentage MHC-II positive higher compared with common carp within faster growth $(42.86 \% 85.71 \%)$.

\section{KEYWORDS: $\begin{aligned} & \text { common carp, growth, resistance, MHC- II, Koi Herpes Virus } \\ & \text { (KHV) }\end{aligned}$}

\section{PENDAHULUAN}

Ikan mas merupakan salah satu komoditas andalan pembudidaya ikan air tawar. Wabah penyakit koi harpes virus atau KHV yang terjadi sejak tahun 2002 merupakan kendala dalam kegiatan budidaya ikan mas sehingga produksinya mengalami kemerosotan yang sangat signifikan. Penyakit infeksi pada ikan ini dapat menyebabkan kematian massal sekitar 80\% 95\% KHV mulai mewabah di Indonesia sejak didatangkannya ikan koi impor dan didistribusikan dari Surabaya ke Blitar, Jawa Timur. Hal ini juga dipicu oleh kondisi cuaca dengan curah hujan yang tinggi sehingga menunjang penyebaran wabah penyakit lebih cepat (Sunarto, 2005).

Penyakit KHV memiliki pola penyebaran yang konsisten dari ikan sakit yang masuk ke lingkungan budidaya dengan sifat penyebaran yang infeksius. Pada sistem kolam air deras di sungai, penyakit ini menyebar ke hilir (bawah) tetapi tidak ke hulu (bagian atas), sehingga penyakit menyebar melalui aliran air. Penyakit KHV tersebar dengan cepat ke seluruh perairan tawar Indonesia, sehingga berbagai upaya dilakukan untuk menangani dan mencegah mewabahnya penyakit ini. Mulai dari penggunaan imunostimulan berupa $\mathrm{Cr}$-yeast yang mampu memberikan respons positif pada peningkatan daya tahan tubuh dan sintasan ikan mas (Mudjiutami et al., 2007). Selain itu, ada pula upaya pemeliharaan ikan mas di perairan bersalinitas $5 \%$, yang relatif lebih tahan terhadap serangan KHV (Saputra et al., 2010). Pemberian vaksin juga merupakan salah satu upaya yang dapat dilakukan untuk mencegah serangan KHV dan dapat menambah sintasan di atas 20\% Namun upaya tersebut pun masih ada kendala yang dihadapi, di antaranya relatif sulit untuk diaplikasikan secara massal.

Penanganan pencegahan yang dilakukan terhadap penyakit infeksi KHV sampai saat ini masih meliputi penambahan sistem pertahanan atau sistem imun dari luar yang biasa disebut inducible. Sementara, pada umumnya ikan teleostei memiliki dua macam sistem imun yaitu sistem imun yang bersifat bawaan atau alamiah (innate) dan dapatan (acquired). Sistem imun pada ikan mirip dengan sistem imun pada mamalia, meskipun akibat perkembangan evolusi menyebabkan ikan memiliki aspek imunitas yang spesifik (Iriyanto, 2005).

Sistem pertahanan spesifik berfungsi untuk melawan penyakit yang memerlukan rangsangan terlebih dahulu, sementara pertahanan non spesifik berfungsi untuk pertahanan terhadap patogen dan bersifat permanen (selalu ada) (Ellis, 1988). Sistem pertahanan spesifik memiliki kemampuan mengenali benda yang dianggap asing bagi dirinya. Sistem imun spesifik terdiri atas humoral, selular, dan organ limfoid. MHC class II termasuk sistem imun spesifik yang bersifat adaptif. Mayor Histocompatibility Complex (MHC) adalah suatu kelompok atau kumpulan gen yang terletak dalam kromosom 6 dan berperan dalam pengenalan dan pemberian sinyal di antara sel- sel sistem imun. MHC class II terdiri atas sel-sel imunokompeten seperti sel $B$, monosit, makrofag, antigen presenting cells (APC), dan sel T aktif yang terdapat pada epitel kelenjar Timus (Baratawidjaja, 1991; Subowo, 1993).

Respons imun biasanya terkait dengan adanya molekul MHC class I dan MHC class II. Sel- sel fagositik akan diaktifkan oleh MHC class II untuk memproduksi antibodi dan mengaktivasi karakter-karakter imunologi yang terlibat dalam mengeliminasi parasit dan bakteri, dan menetralkan virus (Sucipto et al., 2011). Sel- sel fagositik merupakan bagian dari sistem imun yang terdiri atas monosit (prekusor-prekusor makrofag), makrofag, dan granulosit (leukosit granular). Sebagai salah satu gen yang berfungsi menetralkan virus maka gen major histocompatibility complex 
class II (MHC- II), khususnya pada alel Cyca DAB $1 * 05$ dijadikan sebagai penciri molekuler sebagai penanda ikan mas tahan penyakit.

MHC merupakan karakter daya tahan tubuh terhadap penyakit yang dapat dideteksi keberadaannya secara genotip. Selain karakter daya tahan terdapat karakter pertumbuhan yang dapat dilihat secara fenotip, karakter ini juga berperan penting dalam peningkatan produksi secara kualitatif. Menurut Fujaya (2004), pertumbuhan adalah pertambahan ukuran baik panjang maupun bobot. Pertumbuhan dipengaruhi oleh faktor genetik hormon, dan lingkungan. Sementara menurut Hepper \& Prugnin (1984), pertumbuhan ikan dipengaruhi oleh dua faktor, yaitu faktor internal yang meliputi genetik dan kondisi fisiologis ikan, serta faktor eksternal yang berhubungan dengan lingkungan. Pertumbuhan yang lambat merupakan salah satu tanda kualitas genetik ikan yang menurun, selain karakter negatif lainnya yaitu tingkat kematian yang tinggi, kematangan gonad usia dini, dan ukuran individu yang kecil.

Sebagai upaya untuk menanggulangi wabah penyakit KHV terhadap ikan mas, Balai Penelitian Pemuliaan Ikan Sukamandi melakukan pemuliaan terhadap ikan mas melalui perbaikan genetik yaitu secara seleksi pertumbuhan dan seleksi keberadaan marka genetika MHC class II. Hal ini dilakukan untuk membentuk ikan mas tahan Koi Herpes Virus (KHV). Penelitian ini bertujuan untuk melihat hubungan daya tahan ikan mas melalui keberadaan gen Major Histocompatibility Complex (MHC) class II terhadap karakter pertumbuhan (bobot) pada ikan mas Rajadanu populasi dasar G0.

\section{BAHAN DAN METODE}

Penelitian ini dilakukan di laboratorium Balai Penelitian Pemuliaan Ikan (BPPI) Sukamandi, Subang, Jawa Barat. Penelitian ini menggunakan ikan uji dari turunan pertama induk ikan mas strain Rajadanu yang disebut populasi ikan mas G0. Ikan mas G0 merupakan populasi dasar pembentuk ikan mas tahan KHV. Ikan mas G0 yang digunakan berumur tujuh bulan, terdiri atas dua kelompok ukuran. Ukuran besar (404-890 g) merepresentasikan kelompok ikan dengan pertumbuhan cepat dan ukuran kecil (44- $196 \mathrm{~g}$ ) yang merepresentasikan kelompok ikan dengan pertumbuhan lambat.

\section{Pemijahan}

Pemijahan dilakukan secara semi buatan. Jumlah induk yang dipijahkan sebanyak lima pasang. Pemijahan dilakukan pada induk jantan dan betina matang gonad, dilakukan penyuntikan hormon LH-RH guna mempercepat pemijahan, dengan dosis $0,3 \mathrm{~mL} / \mathrm{kg}$ induk betina dan $0,15 \mathrm{~mL} / \mathrm{kg}$ induk jantan. Bobot induk betina yang digunakan berkisar $2-3 \mathrm{~kg} /$ ekor, sedangkan bobot induk jantan berkisar 1,5- $2 \mathrm{~kg}$. Selanjutnya setiap pasangan induk dimasukkan dalam hapa ukuran $2 \mathrm{~m} \times 2 \mathrm{~m}$ x $1,5 \mathrm{~m}$ yang ditempatkan di kolam tanah, dilengkapi aerasi dan substrat yang terbuat dari ijuk sebagai media penetasan telur. Dua belas jam setelah penyuntikan dilakukan pengecekan pada masing- masing hapa. Jika pada substrat sudah terdapat telur, maka induk ikan mas dipindahkan ke dalam kolam pemeliharaan induk. Larva dipelihara sampai hari ke- 7 dengan masa pemanfaatan kuning telur selama tiga hari (endogenous feeding) dan empat hari berikutnya diberikan pakan tambahan (exogenous feeding) berupa suspensi kuning telur ayam yang direbus.

\section{Pendederan}

Benih berumur tujuh hari dipelihara secara komunal di kolam tanah berdinding tembok ukuran $50 \mathrm{~m}^{2}$ dengan kepadatan 25 ekor/ $\mathrm{m}^{2}$. Pemberian pakan buatan berbentuk serbuk dengan kandungan protein kasar sebesar $40 \%$ dilakukan setiap hari secara ad-satiation dengan frekuensi dua kali. Larva dipelihara selama tiga bulan hingga mencapai bobot individu rata- rata 10- $15 \mathrm{~g}$.

\section{Pemeliharaan Pembesaran}

Pemeliharaan pembesaran dilakukan di kolam tanah ukuran $400 \mathrm{~m}^{2}$ dengan kepadatan rendah, yaitu $10 \mathrm{ekor} / \mathrm{m}^{2}$. Selama empat bulan pemeliharaan, ikan diberi pakan buatan berbentuk pelet dengan kandungan protein kasar $28 \%$ Pemberian pakan sebanyak 3\%dari biomassa per hari dan dilakukan dua kali, yaitu pada waktu pagi (09.00) dan sore (16.00). Penyesuaian jumlah pakan yang diberikan dilakukan dengan cara sampling bobot ratarata setiap dua minggu sekali.

\section{Penyiapan Sampel}

Pada akhir bulan ke- 4 dilakukan panen terhadap ikan yang dipelihara. Selanjutnya 
dilakukan seleksi individu ikan untuk mendapatkan populasi ikan dengan ukuran besar dan kelompok ikan dengan ukuran kecil. Kelompok ikan ukuran besar merepresentasikan ikan-ikan dengan pertumbuhan cepat sedangkan kelompok ukuran kecil merepresentasikan ikan- ikan dengan pertumbuhan lambat. Nilai pertumbuhan diinterpretasikan dengan bobot badan ikan. Jumlah sampel ikan sebanyak 28 ekor, diambil secara acak dari masing- masing kelompok sebagai bahan analisis molekuler gen MHC di laboratorium. Bahan analisis molekuler diambil dari organ sirip pada masingmasing sampel ikan. Analisis laboratorium dilakukan dengan ulangan sebanyak empat kali.

\section{Analisis gen MHC}

Secara umum, analisis gen MHC dilakukan melalui tiga tahapan, yaitu ekstraksi DNA sampel, amplifikasi dalam mesin PCR, dan elektroforesis dalam media agarosa gel, berikut adalah tahapannya:

\section{Ekstraksi DNA}

Ekstraksi DNA dilakukan menggunakan metode ekstraksi DNeasy Blood \& Tissue Kits (Qiagen). Sirip ikan mas sebanyak 5- $10 \mathrm{mg}$ dihancurkan, ditambahkan 180 buffer ATL, 20 $\mathrm{mL}$ proteinase $\mathrm{K}$ dan di- vortex, serta diinkubasi pada suhu $56^{\circ} \mathrm{C}$ selama tiga jam. Setelah diinkubasi, sampel di- vortex kembali selama 15 detik, lalu ditambahkan $200 \mu \mathrm{L}$ buffer $\mathrm{AL}$ di-vortex, ditambah $200 \mu \mathrm{L}$ etanol absolute (96\% 100\%, kemudian di-sentrifuge $13.000 \mathrm{rpm}$ selama dua menit. Larutan tersebut dipindahkan ke dalam mini spin colum, di-sentrifuge 6.000-8.000 rpm selama satu menit, cairan pada bagian bawah spin colum dibuang. Spin colum dipindahkan pada tube yang baru, ditambah $500 \mu \mathrm{L}$ Buffer AW1 dan di- sentrifuge pada kecepatan 8.000 rpm selama satu menit, bagian bawah tube dibuang. Spin colum dipindahkan pada tube yang baru, $500 \mu \mathrm{L}$ buffer AW2 ditambahkan dan sentrifuge pada kecepatan 10.000 rpm selama tiga menit. Bagian bawah tube dibuang dengan cara melepas spin colum secara hati- hati jangan sampai bersinggungan dengan cairan bagian bawah colum. Spin colum dipindahkan ke dalam microtube $1,5 \mathrm{~mL}$ yang baru. Selanjutnya ditambahkan $200 \mu \mathrm{L}$ elution buffer $\mathrm{AL}$, diinkubasi satu menit pada suhu ruang dan disentrifuge pada kecepatan 8.000 rpm selama satu menit.

\section{Amplifikasi DNA}

Amplifikasi DNA sampel pada mesin PCR dilakukan dengan kit Maxima Hot Start Green PCR master Mix (2X) (Fermentas, Thermo Scientific). Primer yang digunakan adalah primer spesifik untuk MHC- II pada alel Cyca-DAB $1 * 05$ (Rakus et al., 2008). Komposisi pereaksi PCR di antaranya adalah: $1 \mu \mathrm{L}$ primer forward (CTAATGGATACTACTGG), $1 \mu \mathrm{L}$ primer reverse (ATCGCTGACTGTCTGTT) (Sucipto et al., 2011); $1 \mu \mathrm{L}$ DNA $(450 \mu \mathrm{g} / \mathrm{mL}) ; 12,5 \mu \mathrm{L}$ kit Master mix $\mathrm{PCR}$, dan nuclease free water sampai total volume $25 \mu \mathrm{L}$.

\section{Optimasi Suhu Annealing}

Pada tahap awal PCR dilakukan optimasi suhu annealing terlebih dahulu menggunakan thermocycler gradient (Esco) dengan pengaturan suhu secara otomatis pada kisaran $47^{\circ} \mathrm{C}$ $55^{\circ} \mathrm{C}$. Sampel yang digunakan adalah sampel genom DNA yang sama dan running pada mesin PCR secara bersamaan. Program PCR terdiri atas denaturasi awal pada suhu $95^{\circ} \mathrm{C}$ selama tiga menit, 30 siklus selanjutnya terdiri atas denaturasi pada suhu $95^{\circ} \mathrm{C}$ selama 30 detik, annealing pada suhu kisaran $47^{\circ} \mathrm{C}-55^{\circ} \mathrm{C}$ (pada mesin PCR dihasilkan suhu annealing mulai dari $47^{\circ} \mathrm{C} ; 47,2^{\circ} \mathrm{C} ; 47,6^{\circ} \mathrm{C} ; 48,2^{\circ} \mathrm{C}$; $49,1^{\circ} \mathrm{C} ; 50,2^{\circ} \mathrm{C} ; 51,6^{\circ} \mathrm{C} ; 52,8^{\circ} \mathrm{C} ; 53,6^{\circ} \mathrm{C}$; $54,4^{\circ} \mathrm{C} ; 54,5^{\circ} \mathrm{C} ; 55^{\circ} \mathrm{C}$ ) selama 30 detik dan extension pada suhu $72^{\circ} \mathrm{C}$ selama satu menit. Program diakhiri dengan final extension pada suhu $72^{\circ} \mathrm{C}$ selama tujuh menit dan pengkondisian akhir pada suhu $4^{\circ} \mathrm{C}$. Hasil PCR dapat langsung dielektroforesis atau disimpan dalam freezer. Hasil amplifikasi terbaik pada suhu optimum disimpan sebagai kontrol positif, baik produk PCR maupun Genom DNA yang terdeteksi MHC-II dapat dijadikan kontrol positif.

Setelah diperoleh suhu yang optimum untuk annealing (temperature melting), PCR dilanjutkan pada sampel yang lainnya dengan menggunakan program PCR sebagai berikut: denaturasi awal pada suhu $95^{\circ} \mathrm{C}$ selama tiga menit, 30 siklus selanjutnya terdiri atas denaturasi pada suhu $95^{\circ} \mathrm{C}$ selama 30 detik, annealing pada suhu $49,1^{\circ} \mathrm{C}$ selama 30 detik dan extension pada suhu $72^{\circ} \mathrm{C}$ selama satu menit. Program diakhiri dengan final extension pada suhu $72^{\circ} \mathrm{C}$ selama tujuh menit dan pengkondisian akhir pada suhu $4^{\circ} \mathrm{C}$. Hasil PCR dapat langsung dielektroforesis atau disimpan dalam freezer. Sebagai kontrol internal digunakan gen $\beta$-aktin ikan mas dengan panjang fragmen 
$300 \mathrm{bp}$, primer yang digunakan adalah F: 5'CCC TGG CCC CCA GCA CAA TG- 3' dan R: 5'TCT GCG CAG TTG AGT CGG CG- 3'. Primer $\beta$ aktin didesain dari data base di genebank dengan nomor aksesi M24113.1. Kontrol positif $\beta$-aktin diperoleh dari hasil amplifikasi terhadap genom DNA ikan mas dengan kualitas dan kuantitas yang memadai.

\section{Elektroforesis}

Elektroforesis dilakukan pada gel agarosa dengan konsentrasi sebesar 1,5\%dalam buffer $1 \times$ TBE. Sebanyak $5 \mu \mathrm{L}$ (pada sumur kecil) dan $10 \mu \mathrm{L}$ (pada sumur besar) produk PCR yang sudah terdapat loding dye di dalamnya, dimasukkan ke dalam sumuran agarosa. Deretan produk PCR yang sudah di- loading di- running bersamaan dengan leader marker ukuran 100 bp sebanyak $4 \mu \mathrm{L}$. Elektroforesis dilakukan dengan menggunakan arus listrik $80 \mathrm{~V}$ selama 35 menit. Setelah di- staining menggunakan ethidium bromide, selanjutnya divisualisasikan menggunakan gel doc UV transiliminator

\section{Analisis Data}

Data dianalisis menggunakan analisis korelasi untuk melihat hubungan antara pertumbuhan (bobot) dengan frekuensi kemunculan gen MHC pada masing-masing kelompok ukuran ikan. Analisis data dilakukan dengan menggunakan software program SPSS (Statistical Product and Service Solutions).

\section{HASIL DAN BAHASAN}

Sebagai tahapan awal dari kegiatan penelitian dilakukan optimasi suhu annealing pada PCR MHC- II untuk menghasilkan amplifikasi pada 300 bp. Optimasi suhu dilakukan mulai dari $47^{\circ} \mathrm{C}$ sampai $55^{\circ} \mathrm{C}$. Hasil yang diperoleh dari optimasi annealing yang dilakukan yaitu dapat mengamplifikasi pada suhu $47^{\circ} \mathrm{C}$ sampai $52,8^{\circ} \mathrm{C}$; dan diperoleh band paling tebal pada suhu annealing $49,1^{\circ} \mathrm{C}$ (Gambar 1 ). Hasil ini berbeda dengan penelitian sebelumnya yang dilakukan oleh Sucipto et al. (2011), dengan menggunakan primer yang sama CycaDAB1*05 dan urutan sequence yang sama memiliki suhu annealing untuk dapat mengamplifikasi adalah pada suhu $55^{\circ} \mathrm{C}$.

Berdasarkan hasil deteksi keberadaan gen MHC- II pada ikan mas, diperoleh hasil amplifikasi pada 300 bp pada individu ikan mas. Kemunculan gen MHC- II pada beberapa individu ditunjukkan pada Gambar 2.

Band berukuran 300 bp muncul pada sampel nomor $1,2,4,5,6,7,8,9,10,11$, serta pada kontrol positif, hasil ini menunjukkan bahwa gen MHC- II pada alel Cyca DAB- $1 * 05$ terdeteksi pada tiap sampel tersebut. Sebaliknya pada sampel nomor 3, 12 dan kontrol negatif, band sama sekali tidak muncul, hasil ini menunjukkan bahwa gen MHC-II tidak terdapat pada sampel tersebut. Konfirmasi dari ketidakmunculan gen MHC- II pada beberapa individu ikan mas, telah dilakukan PCR dengan

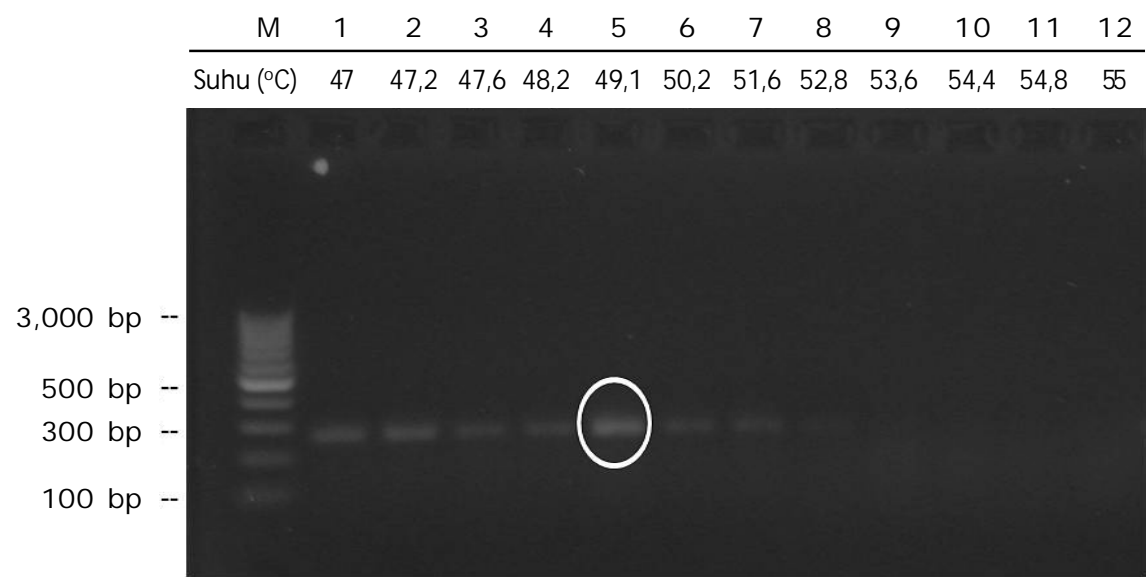

Gambar 1. Optimasi suhu annealing PCR, menggunakan primer Cyca-DAB 1*05 pada mesin thermocycler gradient

Figure 1. Temperature melting PCR optimized, using Cyca-DAB $1 * 05$ primer by thermocycler gradient machine 
J. Ris. Akuakultur Vol. 8 No. 3 Tahun 2013: 383-391

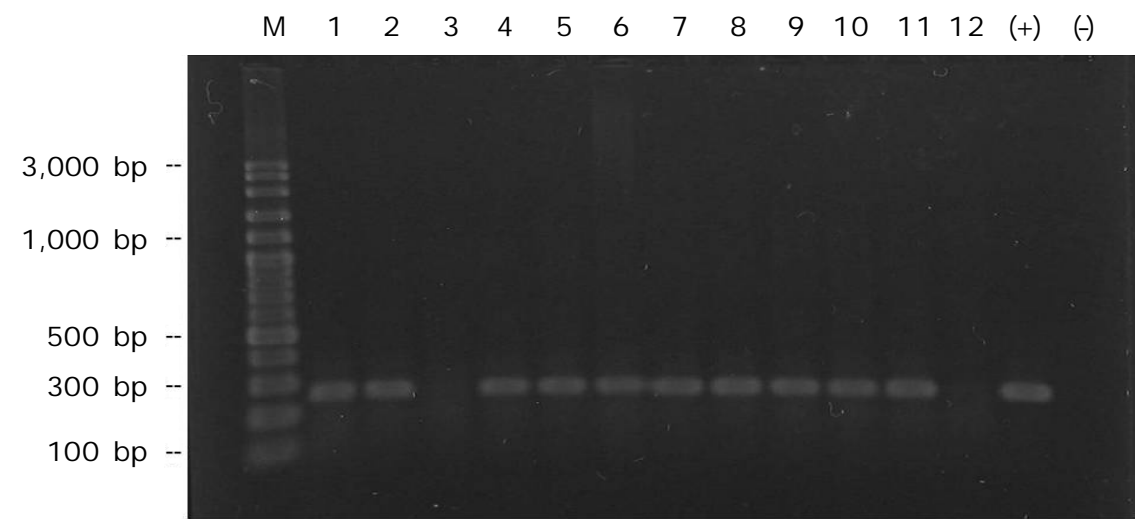

Gambar 2. Amplifikasi gen MHC- II dengan metode PCR menggunakan primer Cyca DAB-1*05 ( $M=$ marker; 1- $2 \& 4-11=$ sampel yang terdeteksi positif MHC- II; $3 \& 12$ = sampel yang negatif MHC- II; (+) = kontrol positif; (- ) = kontrol negatif)

Figure 2. Amplification of MHC-II gene by PCR using Cyca DAB- $1 * 05$ primer $(M=$ marker; $1-2 \& 4-11=$ detected as positive MHC-II; $3 \& 12=$ detected as negative $\mathrm{MHC}-\mathrm{II} ;(+)=$ positive control; $(-)=$ negative control)

menggunakan primer $\beta$-aktin pada seluruh sampel uji dan hasilnya terlihat pada Gambar 3.

Jika amplifikasi $\beta$ - aktin menghasilkan pita DNA pada 300 bp maka genom DNA dari ikan yang negatif MHC-II terbukti genom dalam keadaan baik sehingga dapat dipastikan bahwa ketidakmunculan gen MHC- II bukan dikarenakan atau kualitas dan jumlah genom DNA yang tidak memadai.

Persentase positif MHC- II yang diperoleh dari tiap populasi berdasarkan bobot rata- ratanya divisualisasikan pada Gambar 4. Pada populasi 1- 4 diinterpretasikan sebagai kelompok ikan yang pertumbuhannya lambat. Pada populasi 5- 8 merupakan kelompok ikan yang pertumbuhannya cepat.

Jika dilihat secara deskriptif terlihat perbedaan yang mencolok bahwa persentase MHC- II pada kelompok ikan yang pertumbuhannya lambat memiliki tingkat persentase positif MHC lebih tinggi (85,71\% 100\%) dibandingkan kelompok ikan yang pertum-

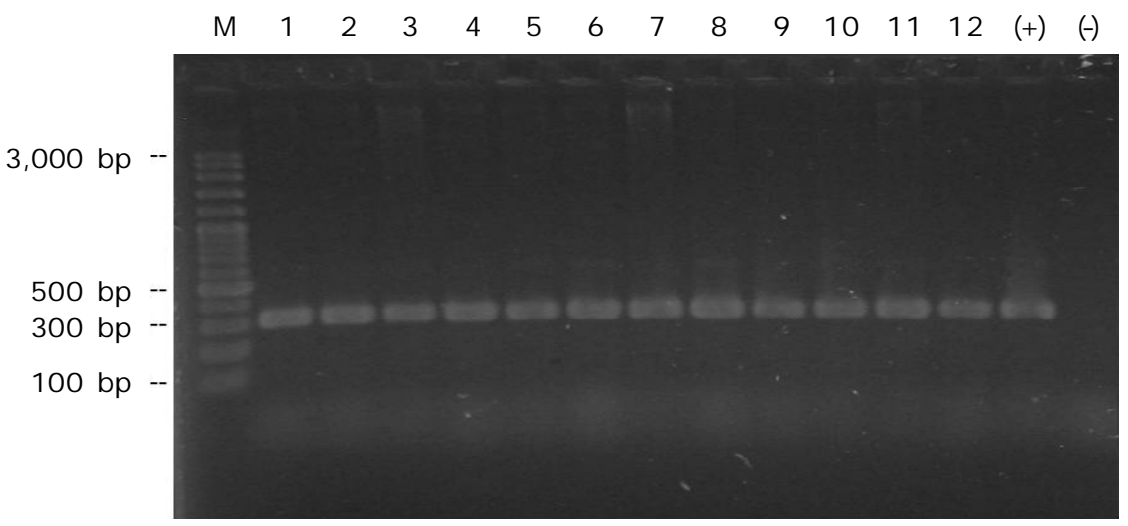

Gambar 3. Amplifikasi gen $\beta$ - aktin ikan mas sebagai kontrol internal dengan PCR (1- 12 = sampel, $(+)=$ kontrol positif, $(-)=$ kontrol negatif)

Figure 3. Amplification of common carp $\beta$-actin as internal control by PCR (112 = sample, $(+)=$ positive control, $(-)=$ negative control) 


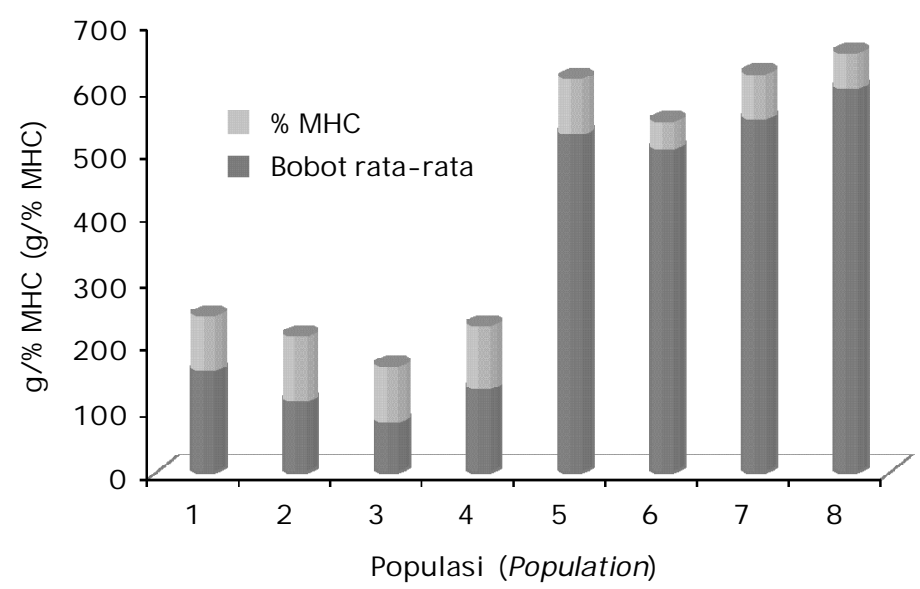

Gambar 4. Hubungan antara bobot rata- rata dengan persentase MHC- II pada masing- masing populasi

Figure 4. Correlation between growth (weight) and MHC-II percentage in each populations

buhannya cepat $(42,86 \% 85,71 \%$. Rendahnya persentase keberadaan MHC class II pada ikan mas yang memiliki pertumbuhan yang cepat dipengaruhi oleh faktor genetik. Faktor genetik tersebut dipicu dari kegagalan dalam aktivasi sel efektor $T$ yang dapat memunculkan gen $\mathrm{MHC}$ class II. Sementara respons sel T bergantung pada interleukin. Gangguan pada makrofag untuk memproduksi interleukin- 1, kurangnya kerja sama di antara subset- subset sel $\mathrm{T}$ dan produksi interleukin- 2 yang menurun akan mengurangi respons imun. Hal tersebut diakibatkan kinerja respons imun yang terhambat oleh tingginya aktivitas gen pertumbuhan (Baratawidjaja, 1991). Hubungan antara pertumbuhan dengan keberadaan MHCII diperkuat melalui analisis korelasi di antara keduanya (Tabel 1 ).

Berdasarkan hasil analisis korelasi menunjukkan adanya korelasi negatif antara bobot rata- rata per populasi yang mewakili

Tabel 1. Hasil analisis korelasi antara pertumbuhan dan persentase MHC- II dengan program SPSS 16

Table 1. Result of correlation level analysis between growth (weight) and MHC-II percentage by SPSS 16 software

\begin{tabular}{clcc}
\hline & & $\begin{array}{c}\text { Bobot ratarata } \\
\text { Average of weight }\end{array}$ & MHC \\
\hline $\begin{array}{c}\text { Bobot ratarata } \\
\text { Average of weight }\end{array}$ & $\begin{array}{l}\text { Nilai korelasi } \\
\text { Pearson correlation (R) } \\
\text { Nilai signifikan / Sig. (2-tailed) }\end{array}$ & 1 & $-0.742^{*}$ \\
& $\mathrm{~N}$ & 8 & 0.035 \\
& Nilai korelasi & $-0.742^{*}$ & 1 \\
\hline MHC-II (MHC-II) & Pearson correlation (R) & 0.035 \\
& Nilai signifikan / Sig. (2-tailed) & 8 & \\
& $\mathrm{~N}$ & 0 & 8 \\
\hline
\end{tabular}

* Nilai korelasi berbeda nyata pada tingkat kepercayaan 0,05 (Correlation is significant at the 0.05 level (2-tailed)) 


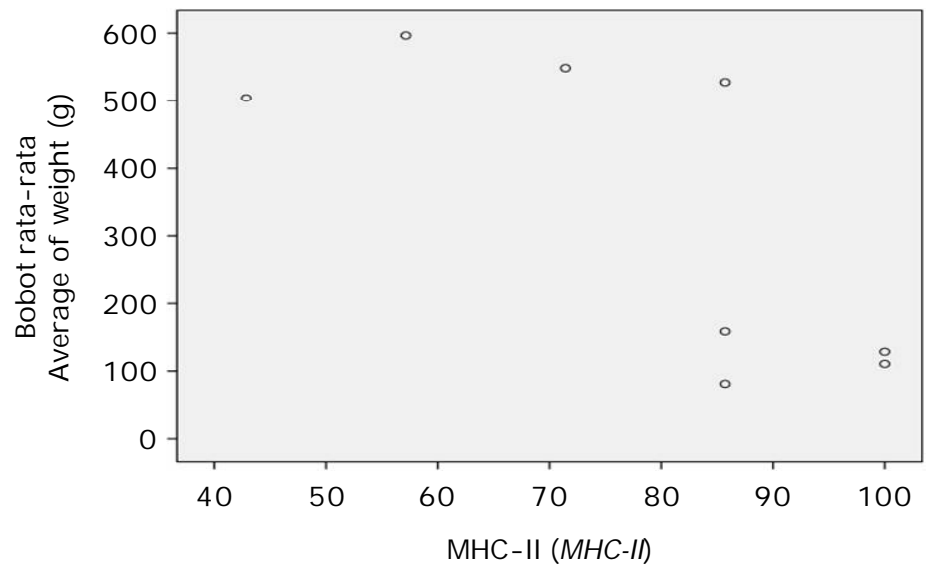

Gambar 5. Skema sebaran pertumbuhan populasi ikan mas terhadap persentase gen MHC- II

Figure 5. Scatter plot the growth of carp populations regarding of MHC-Il gene percentage

pertumbuhan dengan persentase MHC- II sebesar $-74,2 \%$ Korelasi negatif ini mengindikasikan bahwa semakin tinggi bobot ratarata ikan maka semakin sedikit persentase gen MHC-II yang terdeteksi pada setiap populasi. Besarnya pengaruh pertumbuhan terhadap kemunculan gen $\mathrm{MHC}$ - II ditentukan oleh nilai korelasi yaitu $R=-0,742$ atau $-74,2 \%$ dengan tingkat ketelitian $\mathrm{P}<0,05$ atau memiliki hubungan korelasi yang berbeda nyata. Hal ini menandakan bahwa pertumbuhan ikan mas (bobot) memberikan kontribusi sebesar - 74,2\% terhadap persentase ketidakmunculan MHCII. Keberadaan MHC- II pada ikan mas ukuran dewasa dikarenakan adanya respons imun spesifik yang sempurna pada ikan dewasa dan hal ini tidak ditemukan pada ikan muda. Selain itu, ikan muda hanya bergantung pada respons seluler non-spesifik untuk bertahan dari serangan mikroba (Ellis, 1988; Suhermanto et al., 2011). Menurut Ottova et al. (2005), MHC- II merupakan respons imun spesifik pengikat peptida yang dihasilkan oleh degradasi dari protein lain.

Sebaran titik korelasi antara pertumbuhan dengan MHC- II dapat dilihat pada Gambar 5. Pada Gambar 5 terlihat jelas sebaran populasi yang pertumbuhan cepat berada di atas sedangkan populasi yang pertumbuhan yang lambat berkumpul di bawah dan mendekati persentase MHC- II tertinggi. Dari gambar skema sebaran titik, lebih menunjukkan bahwa populasi ikan yang pertumbuhannya cepat memiliki persentase MHC- II yang lebih sedikit sedangkan populasi ikan yang pertumbuhannya lambat memiliki persentase MHC- II lebih banyak hingga mencapai $100 \%$

\section{KESIMPULAN DAN SARAN}

Hubungan antara pertumbuhan dengan gen MHC-II memiliki korelasi yang negatif dengan nilai korelasi $\mathrm{R}=-\mathbf{7 4 , 2} \%$ Semakin cepat pertumbuhan populasi ikan mas maka semakin sedikit persentase individu yang mempunyai gen MHC- II pada setiap populasi tersebut. Sehingga populasi ikan mas yang pertumbuhannya lambat memiliki tingkat persentase positif MHC- II lebih tinggi (85,71\% 100\%) dibandingkan populasi ikan mas yang pertumbuhannya cepat $(42,86 \% 85,71 \%$.

\section{DAFTAR ACUAN}

Baratawidjaja, K.G. 1991. Imunologi dasar. Edisi kedua. Fakultas Kedokteran Universitas Indonesia Press. Jakarta, $222 \mathrm{hlm}$.

Ellis, A.E. 1988. General principles of fish vaccinations. Academic Press. London, p. 119.

Fujaya, Y. 2004. Fisiologi ikan. Rineka citra. Jakarta, 179 hlm.

Herper, B. \& Prugnin, Y. 1984. Commercial fish farming, with the special reference to fish culture in Israel. Jhon Wiley and sons. New York, Chichster, Brisbane, Toronto, $271 \mathrm{pp}$. 
Iriyanto, A. 2005. Patologi ikan teleostei. Gadjah Mada University Press. Yogyakarta, $256 \mathrm{hlm}$.

Mudjiutami, E. , Ciptoroso, Zainun, Z., Sumarjo, $\&$ Rahmat. 2007. Pemanfaatan Imunostimulan untuk pengendalian penyakit pada ikan mas. J. Budidaya Air Tawar, 4(1): 1- 9.

Ottova, E., Simkova, A., Martin, J-F., de Bellocq, J.G., Gelnar, M., Allienne, J- F., \& Morand, S. 2005. Evolution and tans-spesies polymorphism of MHC class IIb genes in cyprinid fish. Fish and Shellfish Immunology, 18: 199- 222.

Rakus, K.L., Wiegertjes, G.F., Adamek, M., Bekh, V., Stet, R.J.M., \& Irnazarow, I. 2008. Application of PCR-RF- SSCP to study maj or histocompatibility class II B polymorphism in common carp (Cyprinus carpio L.). Fish \& Shellfish Immunology, 24: 734- 744.

Saputra, A., Praseno, O., Sudrajat, A., \& Prasetio, A.B. 2010. Pertumbuhan beberapa strain ikan mas yang dipelihara pada tambak bersalinitas rendah. Prosiding Forum Inovasi
Teknologi Akuakultur. Pusat Riset Perikanan Budidaya. Jakarta, hlm. 79- 86.

Subowo. 1993. Imunobiologi. Angkasa. Bandung, $232 \mathrm{hlm}$.

Sucipto, A., Yanti, D.H., Djajanurdjasa, A., \& Muharam, C. 2011. Produksi calon induk ikan mas tahan penyakit. J. Budidaya Air Tawar, hlm. 12- 19.

Suhermanto, A., Andayani, S., \& Maftuch. 2011. Pemberian total fenol teripang pasir (Holothuria scabra) untuk meningkatkan leukosit dan diferensial leukosit likan mas (Cyprinus carpio) yang diinfeksi bakteri Aeromonas Hydrophila. J. Kelautan, 4(2): 49-56.

Sunarto, A. 2005. Epidemologi penyakit koi herpes virus (KHV) di Indonesia. Dalam Supriyadi, H. \& Priono, B. (Eds.) Strategi pengelolaan dan pengendalian penyakit KHV. Pusat Riset Perikanan Budidaya. Jakarta, hlm. 31- 40. 